\title{
A survey on time-varying parameter Taylor rule: A model modified with interest rate pass-through
}

\author{
Ebru Yüksel $^{\mathrm{a}, *}$, Kivilcim Metin-Ozcan ${ }^{\mathrm{b}, 1}$, Ozan Hatipoglu ${ }^{\mathrm{c}, 2}$ \\ ${ }^{a}$ Hacettepe University, Department of Industrial Engineering, 06800 Beytepe, Ankara, Turkey \\ ${ }^{\mathrm{b}}$ Bilkent University, Department of Economics, 06800 Bilkent, Ankara, Turkey \\ ${ }^{\mathrm{c}}$ Bogazici University, Department of Economics, Natuk Birkan Hall, 34342 Bebek, Istanbul, Turkey
}

\section{A R T I C L E I N F O}

\section{Article history:}

Received 9 August 2011

Received in revised form 10 July 2012

Accepted 4 August 2012

\section{JEL classification:}

E43

E52

E58

Keywords:

Extended Kalman filter (EKF)

Interest rate pass-through

Monetary policy

Taylor rule

Time-varying parameter (TVP)

\begin{abstract}
A B S T R A C T
Today, the prime aim of central banking is to achieve price stability and, to a lesser extent, output stability. To this end, central banks use various monetary policy rules. This paper intends to provide a broad survey of the literature on Taylor-type monetary policy rules with a time-varying parameter (TVP) specification. To include the TVP feature, some modification is made in the monetary transmission mechanism of Taylor-type monetary policy models to account for the changing risk preference of individuals. In line with this approach, we introduce an interest rate pass-through specification of the monetary transmission process in a general equilibrium model to account for the varying perceptions of risk by individuals. We include an application for Turkey and estimate the time-variable parameters of the model by employing a structural extended Kalman filter (EKF). The results indicate that the EKF performs better than the standard Kalman filter in estimating the reaction function of the central bank.
\end{abstract}

(C) 2012 Elsevier B.V. All rights reserved.

\section{Introduction}

Recently, New Keynesian models with micro foundations have gained a lot of attention. These models raise interest in reducing inflation volatility and accordingly inflation targeting in order to

\footnotetext{
* Corresponding author. Tel.: +90 31229789 50; fax: +90 3122978953.

E-mail addresses: eyuksel@hacettepe.edu.tr (E. Yüksel), kivilcim@bilkent.edu.tr (K. Metin-Ozcan), ozan.hatipoglu@boun.edu.tr (O. Hatipoglu).

${ }^{1}$ Tel.: +90 31229020 06; fax: +903122665140.

2 Tel.: +90 21235976 40; fax: +90 2122872453 .
} 
establish macroeconomic stability. Today, the prime aim of central banking is to achieve price stability and, to a lesser extent, output stability. According to New Keynesian models, the design of optimal monetary policies and rules are essential in establishing price stability. In this context, as suggested by Taylor (1993) and Woodford (2003), short-term interest rates, used as policy instruments, are key variables. The importance of the use of interest rate patterns for developing efficient monetary policy rules, especially for inflation targeting countries, has been further stressed by Taylor (1999a). Hence, it becomes essential for central banks to determine accurate interest rate rules to achieve price stability in an economy (see, for example, Clarida et al., 1999; Taylor, 1993, 1999b).

In the last decade, considerable attention has been given to the TVP specification of monetary policy rules. There are mainly three factors that necessitate the use of dynamic parameter specification. First, monetary policy rules are based on the attitude of policymakers toward the structure of the economy and contradicting objectives of monetary policy. Therefore, the parameters of interest rate rules are subject to change due to the changing nature of the behavior of policymakers and policy objectives as demonstrated by Favero and Rovelli (2003), Ozlale (2003) and Valente (2003).

Second, central banks utilize a wider information set when devising policy decisions instead of relying only on a single policy rule equation. Thus, for example, if the policy rule is a Taylor-type interest rate rule, ${ }^{3}$ the same levels of output gap and inflation may not produce the same level of interest rate in different periods since the information set used by central banks will be different for each period. The unstable nature of the coefficients of a policy rule can translate into nonlinearities in the central bank's reaction function, which is another issue that should be addressed. For instance, Nobay and Peel (2003) discuss the optimal discretionary monetary policy under the assumption that the central bank has an asymmetric loss function. For monetary policy in the UK, Martin and Milas (2004) concluded that policymakers use discretionary policy for inflation targeting and that monetary policy responds to inflation nonlinearly. Empirically, commensurate with existing asymmetries in the patterns of interest rate setting, Dolado et al. (2005) argued that the European Central Bank's behavior can be explained by the nonlinear optimal policy function, unlike the behavior of the US Fed. Castro (2011) later supported this finding, suggesting that the European Central Bank and the Bank of England follow nonlinear monetary policy rules whereas the US Fed acts according to a linear Taylor rule. However, Petersen (2007) previously found that the monetary policy of the US Fed could be associated with a nonlinear policy rule once inflation approaches a certain threshold. Likewise, Surico (2007) investigated the asymmetric behavior of the monetary policy of the US Fed.

Furthermore, variations in the monetary policy transmission mechanism can be the third reason for the unstable nature of the coefficients of a policy rule. Thus, interest rate rules should be treated as dynamic instead of static. Intuitively, due to shifts in the coefficients of policy rules, studies using stable parameters may be misleading or inefficient in formulating policy advice. Parallel to the Lucas (1976) critique, in order to conduct empirical policy analysis, dynamic parameter models are more appropriate for accounting for policy shifts contrary to fixed parameter models.

The aim of the present survey article is to review the literature on monetary policy rules with a TVP specification for a closed economy. ${ }^{4}$ Following Taylor (1993), numerous works have studied the implications of various versions of the Taylor rule for different countries; as a result, the use of Taylortype interest rate rules in analyzing policy shifts has increased substantially. After a review of the literature, this article evaluates the performance of the Taylor rule in the transition of monetary policy

\footnotetext{
${ }^{3}$ Taylor rules are simple monetary policy rules that prescribe how a central bank should adjust its policy instrument, interest rate, in a systematic manner in response to developments in inflation and macroeconomic activity. Most of the survey papers review the development and characteristics of Taylor rules in relation to alternative monetary policy guides and discuss their role for positive and normative monetary policy analysis as in Orphanides (2007) and Clarida et al. (1999).

${ }^{4}$ The theoretical literature has mainly assumed a closed economy framework. Literature that analyzes the open economy monetary policy tools also exists. But in this survey article we would like to focus only on the interest rate channel rather than the exchange rate channel, since the main open economy alternatives may perform poorly in the face of specific types of exchange rate shocks, such as a rule based on a monetary conditions index (MCI). Since the $\mathrm{MCI}$ is a function of the real exchange rate it is influenced by events such as terms of trade shocks and changes in business and consumer confidence, which do not necessarily affect interest rates.
} 
actions over the economy. The Taylor rule suggests that firms and individuals shape their consumption and investment decisions according to the short-term policy rate, which they face more directly. ${ }^{5}$ In opposition, we argue that individuals do not face the short-term policy rate directly. Instead, depending on their risk and liquidity preferences, firms and households use another interest rate, the long-term market interest rate, ${ }^{6}$ in making their consumption and investment decisions. Thus, to account for the varying risk preference of individuals, we will consider the interest rate passthrough specification in a structural model which, to our knowledge, has not yet been investigated deeply. The added value of our recent survey article is on the time-varying parameter Taylor rule, which is a modified model with interest rate pass-through. To our knowledge this modification has not been included in the Taylor rule specification before.

Our paper contributes to the current debate on the efficiency of Taylor-type rules in explaining the monetary transmission mechanism in an economy. Another important aspect of our article is the introduction of the EKF technique as a new estimation methodology. The fact that the EKF is not widely employed for estimating nonlinear systems in this field makes this study significant for demonstrating the strength of the EKF in predicting TVP models. Thus, this paper mainly contributes to the current literature by applying a mechanical statistical tool to the field of monetary economics. We handle the issue within a system of equations, where we allow the system parameters to vary over time, thereby capturing the volatile nature of macroeconomic variables and the unstable relation between them. These characteristics of the model induce us to employ a nonlinear state space model, where the unobserved state variables and the time-varying parameters, which appear in the model in a nonlinear form, can be estimated simultaneously. In this case, the EKF emerges as an appropriate estimation algorithm. As implied above, such an approach has not yet been employed to study the TVP Taylor rule modified with interest rate pass-through. In Section 2, we provide a literature review on TVP monetary policy rules in detail. Section 3 presents the structural model and its dynamics, while Section 4 introduces the interest rate pass-through specification to our structural model and discusses the efficiency of Taylor-type policy rules. Section 5 gives some brief information about the state space model and the characteristics of EKF. Section 6 estimates the time-variable parameters of the model by employing a structural EKF. Finally, Section 7 concludes the study.

\section{Literature review on TVP monetary policy rules}

Substantial effort is devoted to enacting monetary policy changes and the TVP specification of monetary policy rules. The changes in policy implementation have been captured by various estimation methods such as subsample analysis, generalized method of moments (GMM), least squares (LS), maximum likelihood estimation (MLE), vector autoregression (VAR), smooth transition regression, Markov switching and the Kalman filter.

Judd and Rudebusch (1998) illustrated how the Fed's reaction function has changed over time using ordinary least squares (OLS) and subsample analysis. The study resulted in the parameters of the Taylor-type rule differing significantly for each sub-period considered, indicating that the monetary policy regime varies in time. This study also pointed out the dependency of monetary policy on the attitude of policymakers toward the structure of the economy. Similarly, Clarida et al. (2000) used GMM to show that the US monetary policy changed significantly after Paul Volcker became the chairman of the Fed. Parallel to these studies, Orphanides (2004) provided evidence about the changes

\footnotetext{
${ }^{5}$ This study tries to connect the policy rate and the long-term rates to affect consumption and investment decisions. This analysis can also be performed in close reference with the expectations theory of the yield curve and a critical assessment of the arbitrage condition usually employed to explain the short-term and long-term rate connection. However, this analysis is left as subject matter for further research.

${ }^{6}$ The long-term interest rate plays an important role in the conduct of monetary policy. Especially, the recent financial crisis highlighted the importance of understanding alternative ways to conduct monetary policy. A potential use for long-term nominal interest rates is the possibility of using them as instruments of monetary policy. In fact, previous research suggests that long-term interest rate rules share the desirable properties of Taylor rules, can support unique equilibria, and that their performance is better than that of conventional Taylor rules (see McGough et al., 2005; Kulish, 2007; Gerlach-Kristen and Rudolf, 2010; Jones and Kulish, 2011). In the United States, the United Kingdom, Canada, Japan and the euro area, short rates have been close to zero during the recent crisis, while long rates have remained well above, suggesting that there may be greater capacity to stimulate the economy with long-term rates.
} 
in the interest rate rule of the US using estimations of a forward-looking Taylor rule for two subperiods.

Studies that use the Kalman filter to estimate TVPs of Taylor rule include Elkhoury (2006), Trecroci and Vassalli (2006), Trehan and Wu (2007) and Hatipoglu and Alper (2009). Elkhoury (2006) examined the TVP monetary policy rule for an open economy, Switzerland. The study used the Kalman filter to embed policy shifts and structural changes into the model and found that the uncertainty associated with the policy rule was mostly due to the time-varying characterization of the parameters and, to a lesser extent, monetary shocks. Trecroci and Vassalli (2006) estimated a forward-looking TVP Taylor rule for the UK, Germany, France, Italy and the US using the Kalman filter. The results demonstrated that the countries analyzed have different interest rate rules and that TVP Taylor rules are preferred over fixed parameter rules in capturing the variations in the policy rates. Furthermore, the coefficients of the policy rules change over time in a gradual fashion. Trehan and $\mathrm{Wu}$ (2007) employed the Kalman filter to predict a Taylor rule for the backward-looking US economy, focusing on a time-varying equilibrium real interest rate. Trehan and $\mathrm{Wu}$ (2007) concluded that taking into account time variation in the equilibrium real interest rate makes a substantial difference in the assessment of monetary policy. Hatipoglu and Alper (2009) estimated an augmented Taylor policy rule that responds to an exchange rate gap in the context of emerging markets utilizing Turkish data. To estimate time-varying parameters and unobserved variables such as the exchange rate target and potential output simultaneously, they employ dual EKF, which allows them to trace any changes in central bank behavior, including regime shifts.

Boivin (2006), Jalil (2004), Kim and Nelson (2006) and Mandler (2007) used the Kalman filter and MLE together to estimate a time-varying Taylor rule for the US. Jalil (2004) estimated a TVP backwardlooking Taylor rule with ex-post and real-time data for the US and stated that there are gradual adjustments in the coefficients of the policy rule in the US, which cannot be captured adequately by sub-sample analysis. Boivin (2006) estimated a forward-looking Taylor rule for the US employing the Kalman filter to construct a likelihood function. The conclusion was similar to that of Jalil (2004) and Trecroci and Vassalli (2006) in the sense that the parameters of the Taylor rule were changing gradually. Following Boivin (2006), Kim and Nelson (2006) attempted to characterize a forwardlooking Taylor rule with TVP using ex-post data and a two-step MLE procedure with the Kalman filter to estimate the model. Their empirical results were in favor of the division of the monetary policy history of the US into three periods instead of two (contrary to Orphanides, 2004). Mandler (2007) suggested the use of the Taylor rule with TVPs and an unobserved components model for the output gap together to predict uncertainty in the future values of the Fed rate using the MLE technique via the Kalman filter. Mandler (2007) concluded that the predicted uncertainty can be divided into three types, namely uncertainty due to the time-dependent coefficients of the Taylor rule, uncertainty about future economic events, and residual uncertainty.

Canova and Gambetti (2004), Cogley and Sargent (2001), and Mesonnier and Renne (2007) employed VAR representation with the Kalman filter to model a TVP Taylor rule. Cogley and Sargent (2001) showed empirically that after World War II, policy actions varied significantly with respect to the status of the economy, implying that the coefficients in the policy rule change with time. A similar conclusion was drawn by Canova and Gambetti (2004) as a result of examining changes in the structure of the US economy via a structural VAR framework. Their work differs from Cogley and Sargent (2001) in the sense that structural shocks were also included in their analysis. For the euro area, Mesonnier and Renne (2007) examined the TVP property of the natural rate of interest. The study suggested a Taylor-type policy rule with a time-varying natural rate of interest for the euro area using the Kalman filter.

Plantier and Scrimgeour (2002) estimated the Taylor rule with a TVP specification employing the Kalman filter with OLS to reveal that the neutral real interest rate of New Zealand follows a downward trend in recent years. Horvath (2006) modeled various forms of fixed parameters and TVP Taylor-type rules for the Czech Republic using GMM and the Kalman filter. The results demonstrated that the equilibrium interest rate has decreased steadily over time. In addition to the previous studies involving the euro area, Kuzin (2006) estimated a backward-looking (as opposed to forward-looking) Taylor rule with time-dependent coefficients using Markov switching models and the Kalman filter for Germany only. The conclusion was similar to the work of Trecroci and Vassalli (2006) in that the TVP Taylor rule performed well in capturing the policy shifts. 
Table 1

Summary of literature on TVP policy rules.

\begin{tabular}{|c|c|c|}
\hline Methods & & Articles \\
\hline \multirow[t]{3}{*}{ Subsample } & OLS & Judd and Rudebusch (1998) \\
\hline & GMM & Clarida et al. (2000) \\
\hline & & Surico (2007) \\
\hline \multirow[t]{14}{*}{ Kalman Filter } & & Trehan and Wu (2007) \\
\hline & & Trecroci and Vassalli (2006) \\
\hline & & Elkhoury (2006) \\
\hline & & Hatipoglu and Alper (2009) \\
\hline & MLE & Boivin (2006) \\
\hline & & Jalil (2004) \\
\hline & & Kim and Nelson (2006) \\
\hline & & Mandler (2007) \\
\hline & VAR & Cogley and Sargent (2001) \\
\hline & & Canova and Gambetti (2004) \\
\hline & & Mesonnier and Renne (2007) \\
\hline & OLS & Plantier and Scrimgeour (2002) \\
\hline & GMM & Horvath (2006) \\
\hline & Markov Switching & Kuzin (2006) \\
\hline \multirow[t]{2}{*}{ VAR } & & Sims and Zha (2006) \\
\hline & OLS & Orphanides and Williams (2005) \\
\hline \multirow[t]{3}{*}{ MLE } & Markov Switching & Wesche (2003) \\
\hline & & Wesche (2006) \\
\hline & & Owyang and Ramey (2004) \\
\hline \multirow[t]{3}{*}{ GMM } & & Partouche (2007) \\
\hline & & Castro (2011) \\
\hline & & Dolado et al. (2005) \\
\hline Adaptive LS & & McCulloch (2007) \\
\hline \multirow[t]{3}{*}{ Smooth transition } & & Gerlach and Lewis (2010) \\
\hline & & Martin and Milas (2004) \\
\hline & & Petersen (2007) \\
\hline
\end{tabular}

Orphanides and Williams (2005) adopted time variation in the parameters of the model by allowing agents to update their expectations about the structure of the economy and monetary policy. For this, they used a VAR and OLS framework and investigated changes in the view of the policymakers and monetary policy implementation in the US. Likewise, Sims and Zha (2006) documented inferences about monetary policy changes in the US by allowing time variation in both the coefficients of the Taylor rule and variances of shocks to the economy within a structural VAR framework. Models allowing changes in the parameters of disturbances and the monetary policy function were found to be the best-fit models for the US data.

Wesche (2003) performed a TVP Taylor rule analysis for the countries considered in Trecroci and Vassalli (2006), reaching a similar conclusion despite using a different estimation procedure, a Markov-switching model with independent switching processes for the TVPs of the Taylor rule and variances of disturbances. Later, Wesche (2006) demonstrated the changing preferences of policymakers for interest rate setting in a Markov-switching framework for the US, the UK and Germany. Owyang and Ramey (2004) also employed a Markov-switching model to measure the shifts in the parameters of the policy rule of the US Fed. Parallel to previous works, Partouche (2007) also estimated a forward-looking TVP policy rule for the US. Instead of the Kalman filter this study adopted a different technique, which combined the GMM framework with smoothing splines. Such a technique is not restrictive on econometric terms in that it imposes no constraints on the form of heteroscedasticity of the shock terms and the correlations between the regressors and disturbances. Likewise, McCulloch (2007) estimated a TVP forward-looking Taylor rule for the US using a different method, adaptive least squares (Adaptive LS), to model a time-varying structural VAR framework. Recently, Gerlach and Lewis (2010) used a smooth transition regression model to show the shifts in the parameters of the monetary policy rule of the European Central Bank during the financial crisis. A summary of the literature on TVP policy rules is presented in Table 1. 


\section{The model}

Our baseline macroeconomic framework is described with a dynamic general equilibrium model containing money. We will simply consider the closed economy case. Frictions in the economy are provided by nominal price rigidities, which make the model more realistic (and exclude perfectly flexible price-setting behavior). This rigidity is provided using Calvo (1983) type sticky price-setting. Firms are monopolistically competitive and produce differentiated goods, implying that goods markets are also monopolistically competitive. Infinitely lived households are the owner of the firms, that is, we have producer/consumer agents. The central bank uses a short-term nominal interest rate as the monetary policy instrument. Therefore, money supply is determined endogenously to achieve the determined level of nominal interest rate.

Households buy consumption goods, supply labor and hold bonds (via a financial agent) and money. Firms hire labor, produce differentiated goods and sell them in monopolistically competitive goods markets as given in Dixit and Stiglitz (1977). Using the notation of Walsh (2003), the utility function of the household is described as a function of consumption of differentiated goods $C_{t}$, real money balances $M_{t} / P_{t}$, and time allocated to employment $N_{t}$. The objective of the household is to maximize the present worth of the expected future utility given by

$$
E \sum_{t=0}^{\infty} \beta^{t}\left[\frac{C_{t}^{1-\sigma}}{1-\sigma}+\frac{\gamma}{1-b}\left(\frac{M_{t}}{P_{t}}\right)^{1-b}-\chi \frac{N_{t}^{1+\eta}}{1+\eta}\right]
$$

subject to the budget constraint

$$
C_{t}+\frac{M_{t}}{P_{t}}+\frac{B_{t}}{P_{t}}=\left(\frac{W_{t}}{P_{t}}\right) N_{t}+\frac{M_{t-1}}{P_{t}}+\left(1+i_{t-1}\right)\left(\frac{B_{t-1}}{P_{t}}\right)+\Pi_{t}
$$

where $B_{t}$ is the nominal holdings of one-period bonds, $W_{t}$ is the nominal wage, $\Pi_{t}$ is the real profit transferred from firms and $i_{t}$ is the nominal interest rate faced by households.

The representative firm, on the other hand, maximizes its profit given by

$$
\max _{p_{j t}} E_{t} \sum_{i=0}^{\infty} \omega^{i} \beta^{i}\left(\frac{C_{t+i}}{C_{t}}\right)^{-\sigma}\left[\left(\frac{p_{j t}}{P_{t+i}}\right) c_{j, t+i}-\varphi_{t+i} c_{j, t+i}\right]
$$

where $\omega^{i}$ is the probability of unchanging price of good $j$ from period $t$ to period $t+i$, and $\varphi_{t}$ is the firm's real marginal cost.

At the equilibrium, the Phillip's curve is derived as a function of output gap $x_{t}=y_{t}-y_{t}^{*}$ where $y_{t}$ is the actual output and $y_{t}^{*}$ is the potential output respectively, and the anticipated inflation is as follows:

$$
\pi_{t}=\kappa x_{t}+\beta E_{t} \pi_{t+1}+m_{t}
$$

where $m_{t}$ is a cost-push shock to the New Keynesian Phillips curve.

The aggregate demand curve can be expressed by

$$
x_{t}=E_{t} x_{t+1}-\left(\frac{1}{\sigma}\right)\left(i_{t}-E_{t} \pi_{t+1}\right)+u_{t}
$$

where $u_{t}$ is an exogenous productivity shock.

The fact that the monetary policy influences economic activity in the short term has been widely discussed in the literature (see, for example, Bernanke and Blinder, 1992; Bernanke and Mihov, 1997; Bernanke et al., 1997; Christiano et al., 1996, 1998; Gali, 1992). Monetary policy decisions are used to establish a stable economy in terms of prices and output growth. In this respect, it is necessary to transmit monetary policy actions to macroeconomic variables such as inflation and output so that the interrelations among these variables can produce the grounds of a steady economy. For this purpose, different transmission mechanisms (interest rate, exchange rate, asset prices) are used to disseminate changes in the policy variables to other real and nominal variables. In our model, we used interest rate as the monetary policy tool that transmits the actions of monetary authority to the financial system and real activity. 
In order to specify the monetary transmission mechanism, it is necessary to determine the behavior of monetary policy implemented by the central bank. In the literature, it is common to use a Taylor (1993) type monetary policy rule, which relates the short-term interest rate to both inflation and output gap. Therefore, the Taylor rule is expressed below to close the model:

$$
i_{t}^{p}=i^{*}+\delta_{\pi}\left(E_{t} \pi_{t+1}-\pi^{*}\right)+\delta_{x} E_{t} x_{t+1}+v_{t}
$$

where $i^{*}$ is the desired rate, $\pi^{*}$ is the targeted inflation and $v_{t}$ stands for the shocks to the short-term interest rate.

Typically, the interest rate faced by households and firms (in Eq. (5)) is taken equal to the policy interest rate set by the central bank (in Eq. (6)). Then, the common practice in empirical studies is to perform a simulation and/or empirical study for conducting a monetary policy analysis and extracting policy suggestions using the aforementioned structural equations and monetary policy rule (see, for instance, Ball, 1997; Clarida et al., 1999; Leitemo and Lønning, 2006; Rudebusch and Svensson, 1998; Schmitt-Grohe and Uribe, 2002).

\section{Interest rate pass-through}

In a structural model of monetary policy analysis, the monetary transmission mechanism is of paramount importance. Since policy decisions affect the economy through these transmission channels, the dynamics of propagation mechanisms should be included in a policy analysis. In the literature, it is proposed that policy decisions are transmitted to the economy via the short-term policy interest rate. Such a construction implicitly assumes that households/firms realize the policy interest rate without resorting to information from any media source, and that macroeconomic variables such as inflation and aggregate output are directly affected by the policy rate. Nevertheless, households/ investors in the economy do not realize policy rates directly. On the contrary, short-term policy interest rates are indirectly recognized by agents through the actions of financial institutions (e.g. banks) that collect deposits from households with different maturities and buy bonds from the central bank using these deposits. Since these deposits and credits spread on long horizons, investors require high interest rates to compensate for decreased liquidity and higher credit risk. Hence, the interest rate faced by households is not the short-term policy interest rate but in fact the long-term market interest rate. Changes in the policy rate lead to changes in the long-term rate, which results in changes in investment, consumption and finally aggregate output. Thus, the direction of the monetary transmission mechanism is from policy rate to long-term rate and then to output and inflation. ${ }^{7}$

As in Nelson (2002), application of the expectations theory of the term structure also leads us to the conclusion that the aggregate demand function includes the long-term interest rate instead of the short-term rate. Iterations on Eq. (5) generate

$$
\begin{aligned}
x_{t} & =E_{t} x_{t+1}-\left(\frac{1}{\sigma}\right)\left(i_{t}-E_{t} \pi_{t+1}\right)+u_{t} \\
& =E_{t} x_{t+2}-\left(\frac{1}{\sigma}\right)\left(E_{t} i_{t+1}-E_{t} \pi_{t+2}\right)-\left(\frac{1}{\sigma}\right)\left(i_{t}-E_{t} \pi_{t+1}\right)+E_{t} u_{t+1}+u_{t}=\cdots x_{t} \\
& =-\left(\frac{1}{\sigma}\right)\left(i_{t}^{l}-\pi_{t}^{l}\right)+u_{t}
\end{aligned}
$$

where $i_{t}^{l}=E_{t} \sum_{j=0}^{\infty} i_{t+j} \pi_{t}^{l}=E_{t} \sum_{j=0}^{\infty} \pi_{t+1+j}$ and $u_{t}=E_{t} \sum_{j=0}^{\infty} u_{t+j}$, which is the sum of the expected future demand shocks (productivity shocks).

It is widely accepted that aggregate demand is dependent on long-term interest rates rather than short-term interest rates (see, for instance, Basci et al., 2007; Coricelli et al., 2006; Rotemberg and Woodford, 1999; Taylor, 1995; Woodford, 1999). Since the central bank only uses the short-term

\footnotetext{
${ }^{7}$ However, even though aggregate demand is dependent on long-term interest rates rather than short-term interest rates, the short-term interest rate, or policy rate, also has its direct effects on output and inflation, as is widely recognized in the literature on Taylor rules.
} 
interest rate as a monetary policy tool, there should be a transition equation between the market interest rate and the policy rate, with the intention that by changing the latter, the central bank can impact the economy according to this connection. Although the literature on the interest rate passthrough and the term structure of the interest rate has elaborated on this issue, to our knowledge no attempt has been made to apply the interest rate pass-through specification in a structural model of monetary policy analysis. Therefore, the main contribution of the present paper is the inclusion of the interest rate pass-through specification with a Taylor-type monetary policy rule in a New Keynesian model. Particularly, a TVP interest rate pass-through specification is added to the structural model in a simple way to account for the monetary transmission mechanism in the economy. This specification is also functional in accounting for the changing attitude of investors toward risk. It would not be wrong to claim that such a design could also provide the means for examining the transition from short-term to long-term interest rates under different monetary policies.

Consequently, our contribution to the above model, given by Eqs. (4)-(6), is the inclusion of the interest rate pass-through as a different monetary transmission mechanism. The transition from policy rate to aggregate output and inflation is realized by means of the long-term interest rate. In order to complete the above model, we incorporate the interest rate pass-through relationship, which to our knowledge has not yet been implemented in the literature. The interest rate pass-through relationship establishes the link between the short-term policy rate and the long-term interest rate. Similar to Kwapil and Scharler (2006) and Sørensen and Werner (2006), the long-term interest rate is modeled as a function of its lag, the policy rate and a risk component, which is given below:

$$
i_{t}=\lambda_{1} i_{t-1}+\lambda_{2} i_{t}^{p}+\varepsilon_{t}
$$

where $i_{t}^{p}$ stands for the short-term policy interest rate and $i_{t-1}$ captures the degree of the monetary policy inertia. The interest rate pass-through literature states that the long-term interest rate is positively dependent on its lag and policy rate. Hence, all the coefficients in this equation are expected to be positive. The error component, $\varepsilon_{t}$, captures the risk preference of households and firms.

\subsection{Empirical studies on risk modeling}

The error term in Eq. (7) can be regarded as the risk premium composed of default risk, liquidity factor and inflation risk premium. Default risk accounts for the possibility of a borrower failing to repay the principal and interest payments of a credit on time. Liquidity is another factor that affects the determination of interbank and market interest rates (Hubbard, 2001). The perception of investors toward inflation, which is the inflation risk premium, is the element of $\varepsilon_{t}$ that constitutes the inflation expectations of investors. Since change in the inflation rate is an important determinant of the deposit/ loan rate (market interest rate), the inflation risk premium turns out to be a significant part of the interest rate risk considered in the interest rate pass-through relationship. Therefore, default risk, liquidity and inflation risk premium should be seriously taken into account in empirical models of monetary policy.

The impact of default risk and liquidity on the transition from policy rate to market rate was shown by Martin and Milas (2008) in detail. They investigated the influence of the 2007 sub-prime crisis on the gap between the policy rate, set by the central bank, and the market interest rate, which affects aggregate demand, for the UK. They demonstrated that the difference between the policy rate and the market rate widened during the sub-prime crisis and explained this gap as the combination of mainly unsecured lending risk and the liquidity factor. Martin and Milas (2008) highlighted the increasing difference between the policy rate and the market interest rate during the 2007 sub-prime crisis. They then showed that this difference was mostly a result of unsecured lending risk (default risk) and the liquidity factor. Similarly, Michaud and Upper (2008) empirically illustrated the impact of credit risk and liquidity factors on the gap observed in interbank interest rates. They concluded that interest rate risk is highly influenced by credit risk and liquidity factors.

Hördahl and Tristani (2007) estimated the inflation risk premium for the euro area using a structural macroeconomic model and term structure dynamics. They demonstrated that the inflation risk premium is a significant ingredient in constructing inflation expectations of investors in the euro area. Hördahl (2008), in a subsequent study, measured the inflation risk premium both in the US and 
the euro area by employing the term structure model described in Hördahl and Tristani (2007). The link between the inflation risk premium and the inflation expectations of investors was highlighted in Hördahl (2008) and it was suggested that changes in the inflation risk premium are mostly driven by changes in output. Ang et al. (2008) provided another study that illustrates the correlation between the inflation risk premium and interest rates using a term structure model.

The recent studies above reveal that it is important to consider the interest rate risk, which is included in the interest rate pass-through relationship, and that monetary policy models should take into account the interest rate risk while building monetary transmission mechanisms. Hence, the introduction of the interest rate pass-through relationship as well as the interest rate risk and its components will substantially improve monetary policy models.

\section{A state space model}

The model given by Eqs. (4)-(7) is a computable general equilibrium model, which is composed of both linear and nonlinear equations illustrating the behavior of all households, firms and the central bank in the economy as well as equilibrium conditions (Bergman, 1990). In this section, we propose a structural nonlinear EKF algorithm as a new method for the estimation of time-variable monetary policy parameters.

The studies listed in the literature review section revealed that monetary policy changes are sensitive to the methods employed to model time variation in the coefficients of the interest rate rule and the estimation techniques used. While initial studies were using subsample analysis to chart changes in monetary policies, different techniques were later adopted, such as Markov-switching models, GMM, and the Kalman filter. The Kalman filter (Kalman, 1960) especially is widely utilized due to its aptness in estimating the past, present and future states of a model even if the exact form of the model are not known. Although the standard Kalman filter is an influential technique in estimating linear transformations (Harvey, 1990), it fails to be a reliable technique for nonlinear state space forms. When modeling policy rules and structural equations with TVPs simultaneously, the system takes a nonlinear form, and EKF becomes necessary as the appropriate estimation tool. To the extent of our knowledge, the use of EKF is not as common in monetary policy analysis using TVPs.

In order to facilitate EKF, the model needs to be written in state space form. A state space model is composed of two sets of equations, the system equations representing the evolution of state variables and the observation equations to model the observed state variables. ${ }^{8}$ An appropriate state space setup for the model we proposed above can be written as follows:

$$
\begin{aligned}
& W_{t+1}=A_{t} W_{t}+B_{t} U_{t}+u_{t+1} \\
& Y_{t}=C_{t} W_{t}+D_{t} V_{t}+v_{t}
\end{aligned}
$$

where $W_{t}$ is an $r x 1$ vector of unobserved state variables and $Y_{t}$ is an $n x 1$ vector of observed signals, $U_{t}$ and $V_{t}$ are $k x 1$ and $j \times 1$ predetermined variables. $A_{t}, B_{t}, C_{t}$ and $D_{t}$ are time-dependent parameter matrices. If one allows for time-variable coefficients, the system can be rewritten as

$$
\begin{aligned}
& i_{t}^{p}=i_{t}^{*}+\delta_{\pi, t}\left(E_{t} \pi_{t+1}-\pi_{t}^{*}\right)+\delta_{x, t} E_{t}\left(y_{t+1}-y_{t+1}^{*}\right)+v_{t} \\
& E_{t} \pi_{t+1}=\rho \pi_{t}-\theta x_{t}+k_{t} \\
& E_{t} x_{t+1}=x_{t}-\left(\frac{1}{\sigma}\right)\left(i_{t}^{*}-E_{t} \pi_{t+1}\right)+u_{t} \\
& i_{t}^{*}=\lambda_{1} i_{t-1}+\lambda_{2} i_{t}^{p}+\varepsilon_{t} \\
& y_{t}=y_{t}^{*}+x_{t}
\end{aligned}
$$

\footnotetext{
${ }^{8}$ Explanations about the EKF are standard and adopted from Pasricha (2006), Ribeiro (2004), Welch and Bishop (2006) and Hatipoglu and Alper (2009).
} 
Table 2

Estimation results.

\begin{tabular}{lll}
\hline & Standard & EKF \\
\hline Inflation gap & $1.301(0.492)$ & $1.022(0.704)$ \\
Output gap & $0.039(0.335)$ & $0.012(0.133)$ \\
$\lambda_{1}$ & $0.622(0.061)$ & $0.767(0.049)$ \\
$\lambda_{2}$ & $0.371(0.059)$ & $0.229(0.052)$ \\
Mean square error & 5.653 & 4.441 \\
\hline
\end{tabular}

Note: Standard errors in parentheses except EKF, where MSE is reported. In EKF the parameter value is reported at the last observation.

where $i_{t}^{*}, E_{t} \pi_{t+1}$ and $E_{t} x_{t+1}$ are unobservable state variables, $i_{t}^{p}, \pi^{*}, y_{t}$ and $i_{t}$ are observed signals, and $\delta_{\pi, t}$ and $\delta_{x, t}$ are time-variable policy parameters. Eqs. (10)-(12) are derived from Eqs. (4)-(7) and Eqs. (11) and (13) are slightly modified by making the long-term rates equal to the desired rates to include the effect of interest rate pass-through on policy rates. Eq. (14) is an identity. Moreover, $\rho=1 /$ $\beta, \theta=\kappa \mid \beta$ and $k_{t}=m_{t} \mid \beta$. In addition to Eqs. (10)-(14), we specify the time-variable parameters as a random walk in line with the literature. ${ }^{9}$

$$
\begin{aligned}
& \delta_{\pi, t}=\delta_{\pi, t-1}+\varepsilon_{t} \\
& \delta_{x, t}=\delta_{x, t-1}+\varepsilon_{t}
\end{aligned}
$$

Given our model, we specify the system matrices for the EKF as follows: $W_{t}^{T}=$ $\left[i_{t}^{*}, E_{t} \pi_{t+1}, E_{t} x_{t+1}, \delta_{\pi, t}, \delta_{x, t}\right], Y_{t}^{T}=\left[i_{t}^{p}, y_{t}, 0,0,0\right], U_{t}^{T}=\left[i_{t-1}, \pi_{t}, 0,0,0\right]$, and $V_{t}^{T}=\left[\pi_{t}^{*}, y_{t}^{*}, 0,0,0\right]$, where $T$ denotes the transpose. Parameter matrices are given by $A_{t}=\operatorname{diag}\left\{\lambda_{2}, 0,0,1,1\right\}$, where $A$ is a diagonal $5 \times 5$ matrix with the exceptions $A(1,2)=\lambda_{2} \delta_{\pi, t}, A(1,3)=\lambda_{2} \delta_{x, t}, A(2,3)=-\theta, A(5,2)=A(5,3)=-(1 / \sigma)$, $B_{t}=\operatorname{diag}\left\{\lambda_{1}, \rho, 0,0,0\right\}, C_{t}=\operatorname{diag}\{1,0,0,0,0\}$ with the exceptions $C(1,2)=\delta_{\pi, t}$ and $C(1,3)=\delta_{x, t}$ and $D_{t}=\operatorname{diag}\left\{-\delta_{\pi, \mathrm{t}}, 1,0,0,0\right\}$.

\section{Data and estimation results}

We estimate the model using Turkish data as a case in point. We believe that the Turkish case is particularly interesting because a time-variable rule can resemble the behavior of an emerging market central bank more closely. Both asset and liability dollarization, shallow financial markets, as well as a high current account deficit can lead to fear of sudden capital flights, which might cause an emerging market central bank such as the Central Bank of Turkey (CBT) to shift policies significantly and more frequently.

For the policy rate we use the monthly average of the daily overnight interbank borrowing rate from 2001:01 until 2012:01. Output is calculated as the logarithm of seasonally adjusted real GDP. Inflation is taken to be the logarithmic difference of monthly announced annual CPI after seasonal adjustment. Actual interest rates are market rates announced by the CBT. All data are provided by the CBT.

Our estimation involves several steps. Since the Kalman filter is a recursive procedure, one needs to specify plausible initial values. To do so, we first estimate the parameters of Eq. (10) using OLS. We use these parameters as well as fitted values of the state variables obtained from regressions as initial values. Next, to show the relevance of the methodology employed, we compare efficiency results of the EKF to the standard Kalman filter, where we keep the policy parameters constant. We then estimate the TVP by experimenting with several initial candidates to check for the robustness of the results. Table 2 reports both the efficiency results and the values of the parameters. The EKF parameter is reported at the last observation. According to mean square error (MSE) criteria, EKF performs 15\% better than the standard Kalman filter. The interest rate pass-through is significant and more pronounced under the TVP rule. Another interesting fact to note is that under the TVP estimation, the

\footnotetext{
${ }^{9}$ A comprehensive exposition of the extended Kalman filtering theory can be found in Haykin (2001).
} 
CBT seems to have fought inflation less aggressively, as the average coefficient of the inflation gap for the inflation-targeting period is $1.09 .{ }^{10}$ This result might be due to the presence of a high interest rate pass-through effect.

\section{Conclusion}

For years, the monetary policies implemented by central banks and their influence over the economy and the monetary transmission mechanism have been the research topic of several academics and policymakers. For carrying out monetary policy analysis and examining its impact over the economy, different directions/questions/motivations were adopted for various investigations.

This paper reviewed monetary policy rules with a TVP specification. The changing behavior of policymakers, full or partial use of the information set available, and the unstable structure of the economy are the main reasons for requiring the employment of TVP characterization. In the light of this analysis, we claimed that changes in the risk preferences of households and firms should also be reflected in such a world. One of the ways of doing this is to include the risk attitude of households in the formation of the market interest rate faced by investors and creditors. For this, we differentiated the short-term interest rate determined by the central bank and the long-term interest rate faced by households. This differentiation should be made especially in empirical studies to increase the robustness of the conclusions. Next, we stressed that the changing behavior of investors toward risk should be considered as a component in the determination of the long-term market interest rate. This construction is given by the interest rate pass-through specification. Through this method, the changing risk preferences of households and firms can be considered in a structural model, which could be worthwhile for real-time data applications.

Finally, we specified a state space model with the interest rate pass-through within which we can utilize the EKF to estimate a TVP Taylor rule. By utilizing Turkish data we showed that the EKF performed better than the standard Kalman filter in estimating the CBT reaction function. A future study might look into the role of the exchange rate pass-through together with the interest rate passthrough in a Taylor-type reaction function. We believe the role of exchange rates in determining the expected inflation as well as the output gap in a TVP rule is not adequately analyzed.

\section{References}

Ang, A., Bekaert, G., Wei, M., 2008. The term structure of real interest rates and expected inflation. Journal of Finance 63, 797-849.

Ball, L., 1997. Efficient rules for monetary policy. NBER Working Paper 5952, Cambridge, MA.

Basci, E., Ozel, O., Sarikaya, C., 2007. The monetary transmission mechanism in Turkey: New developments. Central Bank of the Republic of Turkey Research and Monetary Policy Department Working Paper 07/04, Ankara.

Bergman, L., 1990. The development of computable general equilibrium modeling. In: Bergman, L., Jorgenson, D.W., Zalai, E. (Eds.), General Equilibrium Modeling and Economic Policy Analysis. Basil Blackwell, Cambridge, MA, pp. 3-30.

Bernanke, B.S., Blinder, A.S., 1992. The federal funds rate and the channels of monetary transmission. American Economic Review 82, 901-921.

Bernanke, B.S., Mihov, I., 1997. What does the Bundesbank target? European Economic Review 41, 1025-1053.

Bernanke, B.S., Gertler, M., Watson, M., 1997. Systematic monetary policy and the effects of oil price shocks. Brookings Papers on Economic Activity 1, 91-157.

Boivin, J., 2006. Has U.S. monetary policy changed? Evidence from drifting coefficients and real-time data. Journal of Money, Credit and Banking 38, 1149-1173.

Calvo, G.A., 1983. Staggered prices in a utility-maximizing framework. Journal of Monetary Economics 12, 383-398.

Canova, F., Gambetti, L., 2004. Structural changes in the US economy: bad luck or bad policy? CEPR Discussion Papers 5457, London.

Castro, V., 2011. Can central banks' monetary policy be described by a linear (augmented) Taylor rule or by a nonlinear rule? Journal of Financial Stability 7, 228-246.

Christiano, L.J., Eichenbaum, M., Evans, C., 1996. The effects of monetary policy shocks: evidence from the flow of funds. Review of Economics and Statistics 78, 16-34.

Christiano, L.J., Eichenbaum, M., Evans, C., 1998. Monetary policy shocks: What have we learned and to what end? NBER Working Papers 6400, Cambridge, MA.

Clarida, R., Gali, J., Gertler, M., 1999. The science of monetary policy: a new Keynesian perspective. Journal of Economic Literature 37, 1661-1707.

\footnotetext{
10 This number is obtained by taking the simple arithmetic average of the coefficient values between 2006:01, when the CBT started announcing explicit inflation targets, and 2012:01.
} 
Clarida, R., Gali, J., Gertler, M., 2000. Monetary policy rules and macroeconomic stability: evidence and some theory. Quarterly Journal of Economics 115, 147-180.

Cogley, T., Sargent, T.J., 2001. Evolving post-World War II U.S. inflation dynamics. NBER/Macroeconomics Annual 16, 331 -373.

Coricelli, F., Égert, B., MacDonald, R., 2006. Monetary transmission mechanism in Central and Eastern Europe: Gliding on a wind of change. The William Davidson Institute at the University of Michigan Working Paper 850, Ann Arbor, MI.

Dixit, A.K., Stiglitz, J.E., 1977. Monopolistic competition and optimum product diversity. American Economic Review 67, 297-308.

Dolado, J., Dolores, R., Naveira, M., 2005. Are monetary policy reaction functions asymmetric? The role of nonlinearity in the Phillips curve. European Economic Review 49, 485-503.

Elkhoury, M., 2006. A time-varying parameter model of a monetary policy rule for Switzerland: The case of the Lucas and Friedman hypothesis. HEI Working Papers 01-2006, Geneva.

Favero, C.A., Rovelli, R., 2003. Macroeconomic stability and the preferences of the Fed: a formal analysis, 1961-98. Journal of Money, Credit and Banking 35, 545-556.

Gali, J., 1992. How well does the IS/LM model fit post-war U.S. data? Quarterly Journal of Economics 92, 709-738.

Gerlach-Kristen, P., Rudolf, B., 2010. Financial shocks and the maturity of the monetary policy rate. Economics Letters 107 , 333-337.

Gerlach, S., Lewis, J., 2010. The zero lower bound, ECB interest rate policy and the financial crisis. De Nederlandsche Bank Working Paper 254, Amsterdam.

Harvey, A.C., 1990. Forecasting, Structural Time Series Models and the Kalman Filter. Cambridge University Press, Cambridge.

Hatipoglu, O., Alper, E., 2009. Estimating central bank behavior in small open economies. In: Cobham, D., Dibeh, G. (Eds.), Central Banking in Middle East and North Africa. Routledge, New York, pp. 50-72.

Haykin, S., 2001. Kalman Filtering and Neural Networks. Wiley Publishers, Hoboken, NJ.

Horvath, R., 2006. Real-time time-varying equilibrium interest rates: Evidence on the Czech Republic. MPRA Paper 845, Munich.

Hördahl, P., 2008. Inflation risk premium in the term structure of interest rates. BIS Quarterly Review September, 23-38.

Hördahl, P., Tristani, O., 2007. Inflation risk premia in the term structure of interest rates. BIS Working Papers 228, Basel.

Hubbard, R.G., 2001. Money, the Financial System, and the Economy. Addison Wesley, New York.

Jalil, M.A., 2004. Monetary Policy in Retrospective: A Taylor Rule Inspired Exercise. Manuscript. University of California, San Diego, CA.

Jones, C., Kulish, M., 2011. Long-term interest rates, risk premia and unconventional monetary policy. Reserve Bank of Australia Research Discussion Papers 2011-02, Sydney.

Judd, J.P., Rudebusch, G.D., 1998. Taylor's rule and the Fed: 1970-1997. Federal Reserve Bank of San Francisco Economic Review 3, 3-16.

Kalman, R.E., 1960. A new approach to linear filtering and prediction problems. Journal of Basic Engineering 35-45.

Kim, C.-J., Nelson, C.R., 2006. Estimation of a forward-looking monetary policy rule: a time-varying parameter model using expost data. Journal of Monetary Economics 53, 1949-1966.

Kulish, M., 2007. Should monetary policy use long-term rates? The B.E, Journal of Macroeconomics 7, 15.

Kuzin, V., 2006. The inflation aversion of the Bundesbank: a state space approach. Journal of Economic Dynamics and Control 30 , 1671-1686.

Kwapil, C., Scharler, J., 2006. Interest rate pass-through, monetary policy rules and macroeconomic stability. Austrian Central Bank Working Papers 118, Vienna.

Leitemo, K., Lønning, I., 2006. Simple monetary policymaking without the output gap. Journal of Money, Credit and Banking 38, 1619-1640.

Lucas, R., 1976. Econometric policy evaluation: a critique. Journal of Monetary Economics (Suppl.), 19-46.

Mandler, M., 2007. The Taylor rule and interest rate uncertainty in the U.S. 1955-2006. MPRA Paper 2340, Munich.

Martin, C., Milas, C., 2004. Modelling monetary policy: inflation targeting in practice. Economica 71, $209-221$.

Martin, C., Milas, C., 2008. The sub-prime crisis and UK monetary policy. In: Workshop on Methods and Applications for Macroeconomics and Finance, Proceedings, Ege University Faculty of Economics and Administrative Sciences, Ege Basim, Izmir, pp. 46-72.

McCulloch, J.H., 2007. Adaptive least squares estimation of the time-varying Taylor rule, Ohio State University Working Paper, Columbus, $\mathrm{OH}$.

McGough, B., Rudebusch, G.D., Williams, J.C., 2005. Using a long-term interest rate as the monetary policy instrument. Journal of Monetary Economics 52, 855-879.

Mesonnier, J.-S., Renne, J.-P., 2007. Does uncertainty make a time-varying natural rate of interest irrelevant for the conduct of monetary policy? Banque de France Working Paper 175, Paris.

Michaud, F.-L., Upper, C., 2008. What drives interbank rates? Evidence from the Libor panel. BIS Quarterly Review 2008 (March), 47-58.

Nelson, E., 2002. Direct effects of base money on aggregate demand: theory and evidence. Journal of Monetary Economics 49, 687-708.

Nobay, R., Peel, D., 2003. Optimal discretionary monetary policy in a model of asymmetric central bank preferences. Economic Journal 113, 657-665.

Orphanides, A., 2004. Monetary policy rules, macroeconomic stability, and inflation: a view from the trenches. Journal of Money, Credit and Banking 36, 151-175.

Orphanides, A., Williams, J.C., 2005. The decline of activist stabilization policy: natural rate misperceptions, learning, and expectations. Journal of Economic Dynamics and Control 29, 1927-1950.

Orphanides, A., 2007. Taylor Rules. Finance and Economics Discussion Series No. 2007-18. Board of Governors of the Federal Reserve System, Washington, DC.

Owyang, M., Ramey, G., 2004. Regime switching and monetary policy measurement. Journal of Monetary Economics 51, 15771597.

Ozlale, U., 2003. Price stability vs. output stability: Tales of Federal Reserve administrations. Journal of Economic Dynamics and Control 27, 1595-1610. 
Partouche, H., 2007. Time-varying coefficients in a GMM framework: Estimation of a forward looking Taylor rule for the Federal Reserve. Banque de France Working Paper 177, Paris.

Pasricha, G.K., 2006. Kalman filter and its economic applications. University of California, Santa Cruz, CA, unpublished manuscript.

Petersen, K., 2007. Does the Federal Reserve follow a non-linear Taylor rule? University of Connecticut, Department of Economics Working Paper 37, Storrs, CT.

Plantier, L.C., Scrimgeour, D., 2002. Estimating a Taylor rule for New Zealand with a time-varying neutral real rate. Reserve Bank of New Zealand Discussion Paper Series DP2002/06, Wellington.

Ribeiro, M.I., 2004. Kalman and extended Kalman filters: concept, derivation and properties. Institute for Systems and Robotics, Lisboa, unpublished manuscript.

Rotemberg, J.J., Woodford, M., 1999. Interest-rate rules in an estimated sticky-price model. In: Taylor, J.B. (Ed.), Monetary Policy Rules. NBER Conference Report Series. University of Chicago Press, Chicago, IL, pp. 57-126.

Rudebusch, G.D., Svensson, L.E.O., 1998. Policy rules for inflation targeting. NBER Working Papers 6512, Cambridge, MA.

Schmitt-Grohe, S., Uribe, M., 2002. Optimal fiscal and monetary policy under sticky prices. NBER Working Papers 9220 , Cambridge, MA.

Sims, C.A., Zha, T., 2006. Were there regime switches in U.S. monetary policy? American Economic Review 96, 54-81.

Sørensen, C.K., Werner, T., 2006. Bank interest rate pass-through in the euro area: A cross country comparison. European Central Bank Working Paper Series 580, Frankfurt/Main.

Surico, P., 2007. The Fed's monetary policy rule and US inflation: the case of asymmetric preferences. Journal of Economic Dynamics and Control 31, 305-324.

Taylor, J.B., 1993. Discretion versus policy rules in practice. In: Carnegie-Rochester Conference Series on Public Policy, 39. pp. $195-214$.

Taylor, J.B., 1995. The monetary transmission mechanism: an empirical framework. Journal of Economic Perspectives 9, 11-26.

Taylor, J.B., 1999a. A historical analysis of monetary policy rules. In: Taylor, J.B. (Ed.), Monetary Policy Rules. NBER Conference Report Series. University of Chicago Press, Chicago, IL, pp. 319-341.

Taylor, J.B., 1999b. Monetary policy rules. NBER Conference Report Series. University of Chicago Press, Chicago, IL and London.

Trecroci, C., Vassalli, M., 2006. Monetary policy regime shifts: New evidence from time-varying interest rate rules. University of Brescia, Department of Economics, Brescia. Discussion Paper 0602.

Trehan, B., Wu, T., 2007. Time-varying equilibrium real rates and monetary policy analysis. Journal of Economic Dynamics and Control 31, 1584-1609.

Valente, G., 2003. Monetary policy rules and regime shifts. Applied Financial Economics 13, 525-535.

Walsh, C.E., 2003. Monetary Theory and Policy. MIT Press, Cambridge, MA and London.

Welch, G., Bishop, G., 2006. An introduction to the Kalman filter. Department of Computer Science, University of North Carolina, Chapel Hill, NC, unpublished manuscript.

Wesche, K., 2003. Monetary policy in Europe: Evidence from time-varying Taylor rules. Bonn Econ Discussion Papers bgse21_2003, Bonn.

Wesche, K., 2006. Estimating central banks' preferences from a time-varying empirical reaction function. European Economic Review 50, 1951-1974.

Woodford, M., 1999. Optimal monetary policy inertia. NBER Working Papers 7261, Cambridge, MA.

Woodford, M., 2003. Interest and Prices. Princeton University Press, Princeton, NJ, and Oxford. 